\title{
ABSTRACT OF SANITARY REPORTS RECEIVED DURING THE PAST WEEK UNDER THE NATIONAL QUARANTINE ACT. - No. VIII.
}

Office Surgeon-General U. S. M. H. S., Washington, August 31, 1878.

New Orleans. - During the week ended yesterday noon there were 1204 cases of yellow fever and 333 deaths, making in all 2877 cases and 867 deaths. During the twenty-four hours to noon yesterday there were 169 new cases and 59 deaths.

Vicksburg. - During the week ended yesterday evening there were 116 deaths from yellow fever, making 185 deaths in all, 17 of which occurred during the last twenty-four hours. It is estimated that eight hundred cases of fever have occurred to date, about half of these in the past week, and 59 new cases in the last twenty-four hours. Dr. Booth, in charge of the patients of the marine hospital service, died the $27 \mathrm{th}$.

Meмpнis. - Seven hundred and twenty-one cases of yellow fever and 241 deaths for the week ended August 29th.

Morann City, LA.- The refugee reported last week sick of yellow fever died August 23d. Seven other cases have since occurred, and four deaths in all to yesterday noon.

BAx ST. Lours, LA. - One death from yellow fever occurred the 18th inst.

Ucean Springs, Mrss. - Three cases of yellow fever occurred yesterday morning. No deaths during the week.

Water VALley, Miss. - Two cases of yellow fever, both refugees; the first occurred on the 12 th and is convalescent; the second on the $26 \mathrm{th}$, which terminated fatally yesterday.

Holly Springs, Miss. - Seven cases of yellow fever and two deaths to yesterday evening, - all refugee:. Good health in the city and the United States military camp.

Leighton, Ala. - A refugee from Memphis arrived August 18th and died of yellow fever August 24th.

ST. Lovis. - Eight cases of yellow fever during the week and two deaths, all refugees. At quarantine, below St. Louis, there were six new cases and one death, besides twenty doubtful cases admitted during the forty-eight hours ended yesterday evening.

Cairo, ILl. - A river boatman from Memphis died of yellow fever August 24th.

Louisville. - Since last report eleven refugees and boatmen bave been attacked with yellow fever after arrival in Louisville, four of whom have died.

Cincinnati. - Nine cases of yellow fever - five from steamboat Golden Rule - and four deaths have occurred since last report. Two of the deaths were the cases reported last week. All came from infected places south.

Whencing, W. VA. - Case reported through the Press on the 28th officially pronounced not yellow fever.

Pitcsiorg, PA. - A deck-hand on the steamboat John A. Porter arrived August 25th, and died next day of yellow fever.

Philadelphia. - Two cases of probable yellow fever occurred August 24th, the persons having arrived from Vicksburg a few hours previously. They were immediately removed to the hospital for infectious diseases.

Havana. - Seventy-one deaths from yellow fever and six from small-pox during week ended August 24th.

Chifton, Enerand. - The United States consul at Bristol, England, reports a severe outbreak of enteric (typhoid) fever at Clifton, near that place, which had been traced to the use of milk from a farm where the pump is five yards from the privy vault. Previous to the outbreak a young lady had been carried to the farm-house to complete her convalescence from enteric fever. $\Lambda$ wholesome lesson is given in the action of the medical officer of health, who notified the farmer that if he let any member of his family use the contaminated pump water and disease arose from it, or if he sold any milk and disease arose from it, he would lay information against him of having committed manslaughter.

Trieste, Ausrria. - Some cases of the plague have occurred at Trieste. Advices to August 17th.

No reliable information received from Key West, and no official reports obtained from Grenada, Canton, and Port Gibson, Miss., and Port Eads, La.

Reports from other places indicate good health.

JOHN M. WOODwORTE, Surgeon-General U. S. Marine Hospital Service. 